\title{
Collective Layoffs: Protection of Employees against Dismissal or Displacement as a Result of Mergers, Closings, or Work Transfers
}

Phillip Blumberg

University of Connecticut School of Law

\section{Recommended Citation}

Blumberg, Phillip, "Collective Layoffs: Protection of Employees against Dismissal or Displacement as a Result of Mergers, Closings, or Work Transfers" (1978). Faculty Articles and Papers. 144.

https://opencommons.uconn.edu/law_papers/144 


\section{HEINONLINE}

Citation: 26 Am. J. Comp. L. Sup. 277 1977-1978

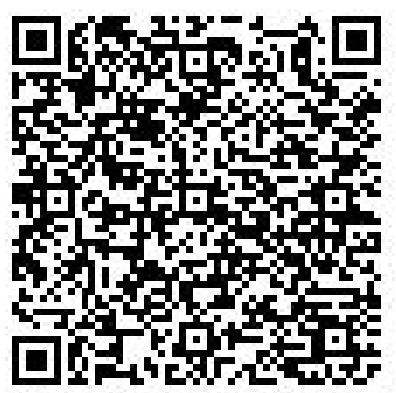

Content downloaded/printed from

HeinOnline (http://heinonline.org)

Tue Aug 16 12:49:24 2016

-- Your use of this HeinOnline PDF indicates your acceptance of HeinOnline's Terms and Conditions of the license agreement available at http://heinonline.org/HOL/License

-- The search text of this PDF is generated from uncorrected OCR text.

-- To obtain permission to use this article beyond the scope of your HeinOnline license, please use:

https://www.copyright.com/ccc/basicSearch.do?

\&operation $=$ go\&search $T y p e=0$

\&lastSearch $=$ simple\&all=on\&titleOrStdNo=0002-919X 


\title{
Collective Layoffs: Protection of Employees Against Dismissal or Displacement as a Result of Mergers, Closings, or Work Transfers
}

\author{
Phillip I. Blumberg*
}

Labor in the United States has made limited progress with respect to the protection of employees against collective layoffs, arising from mergers, plant closings, plant relocations, or work transfers.

In the area of regulated industries, particularly transportation, governmental control over mergers, acquisitions, and abandonments has been a cornerstone of the regulatory process. Labor has been widely successful in achieving legislative and administrative recognition that the terms of such governmental approval must take into account the protection of the interests of affected employees.

In other areas, in keeping with the uniquely different pattern of American labor relations, employee protection against collective layoffs-where it exists at all-is found almost entirely in collective bargaining agreements rather than in statute or administrative regulation. Only a minority of collective agreements, however, restrict employer discretion. Employers are generally free to decide such matters as mergers, plant closings and relocations without the need for labor approval, or even consultation; wider union participation may be found in the case of work transfers and subcontracting. However, even where employers may freely decide such matters, the National Labor Relations Act imposes an obligation upon them to bargain with unions on the impact of such decisions on their employees.

\section{Public Law Making: Statutory and Administrative Protection Against Collective Layoffs}

In contrast to American industry generally, government intervention, combined with collective bargaining agreements, in a number of regulated industries, particularly in the transportation area, has provided significant protection for employees affected by collective layoffs.

\section{The Scope of Federal Intervention}

In the case of railroads, trucking, airlines, and urban mass transportation, federal legislative and administrative action has provided shelter for

* Dean, University of Connecticut School of Law. 
employees from the consequences of layoffs or displacement as a result of mergers, acquisitions, and abandonments. ${ }^{1}$

\section{Railroads}

The initial federal intervention in this area was the Emergency Railroad Transportation Act of $1933 .^{2}$ Among other things, it protected all railroad employees against dismissal or reduction in pay as the result of railroad actions undertaken under the Act and prohibited any reduction in rail employment below the May 1933 payroll level, less $5 \%$ attrition per year. The statute applied to the railroads generally and was not restricted to the adverse impact on employment of specific developments, such as mergers, or abandonments. The 1933 Act was generally unsatisfactory and allowed to expire in 1936.

In an interesting development, the unsatisfactory statute was replaced not by an improved statute, but by a collective agreement between 20 major railroad unions and $85 \%$ of the railroad industry. The Washington Job Protection Agreement of 1936 substituted an elaborate program of severance and displacement pay for the prohibitions on employment termination contained in the expired statute. In the event of layoff from mergers and abandonments, the affected worker was assured of $60 \%$ of his pay for up to 5 years, depending on his length of service. The Washington Job Protection Agreement also provided for displacement allowances for 5 years for employees retained at lower pay, moving expenses, and other benefits. ${ }^{3}$ Thus, the rail industry recaptured the ability to reduce its work force but at the price of an obligation to provide substantial compensation to affected employees.

These collective agreements were subject to enforcement through the machinery of the Railway Labor Act. ${ }^{4}$

The Washington Job Protection Agreement established a pattern for severance and displacement pay protection for affected employees that was followed in later legislation and collective agreements. Subsequent railroad collective agreements enlarged the provisions of the Washington Job Protection Agreement to cover layoffs from causes other than merger and abandonment. This reflected increasing concern with job losses as a result of tech-

1. See Brown, Employee Protection and the Regulation of Public Utilities, Mergers, Consolidations, and Abandonment of Facilities in the Transportation Industry, 63 YALE L.J. 445 (1954); Rosenfield, Airline Mergers: The Public Interest in Labor Protective Provisions, 61 KY. L.J. 429 (1973); Newborn, Protection of Employees in Railroad Consolidations under the Interstate Commerce Act, 23 Lab. L.J. 207 (1972); Murray, $A$ New Look at Rail Employee Merger Protection, Norfolk \& Western R.R. v. Nemitz, An Assessment. 24 CASE W. RES. L. REV. 103 (1972).

2. 48 Stat. 211 (1933).

3. 80 CONG. REC. 7666-70 (1936). The scale of severance pay was as follows:

Service

1- 2 years

2- 3 years

3. 5 years

5-10 years

$10-15$ years

15 years

4. 45 U.S.C. \& 153 et seq. (1972).

$$
\begin{array}{r}
\text { Payment } \\
1 / 2 \text { year } \\
1 \text { year } \\
\text { 1-1/2 years } \\
3 \text { years } \\
4 \text { years } \\
5 \text { years }
\end{array}
$$


nological change and reorganization. By 1965, 395,000 non-operating rail employees were covered by contracts providing severance pay, income maintenance, and relocation moving allowances for employees affected by such events. Such job protective provisions did not include layoffs caused by declining business. ${ }^{5}$

From 1936 to 1940 , there was no federal statute expressly protecting railroad employees against the loss or impairment of employment as a result of mergers. During this period, the Interstate Commerce Commission ("the Commission") used its discretion to include labor protective provisions in orders approving railroad mergers under its general statutory power to impose conditions required to render the proposal "consistent with the public interest" as part of its determination of merger applications. ${ }^{6}$ This followed a precedent established by the Commission as early as 1934 when it approved a terminal acquisition on condition that seniority of the acquired employees be protected. ${ }^{7}$ Discretionary employee protection by the Commission was upheld by the Supreme Court in the Lowden case. ${ }^{8}$

In 1940, the Interstate Commerce Act was amended to substitute mandatory statutory protection for employees for the previous system of discretionary administrative relief. Section $5(2)(f)$ mandated that the Commission in approving railroad mergers "require a fair and equitable arrangement to protect the interests of the railroad employees affected" and protect employees against adverse effect on employment relations for a period of four years. $^{9}$ In effect, the amendment followed the pattern of the Washington Job Protection Agreement.

In subsequent litigation, the Supreme Court construed the four-year period of the 1940 amendment to run from the effective date of the Commission order rather than from the earlier date on which the employee was adversely affected, thereby significantly extending the period of coverage. ${ }^{10}$ The Supreme Court subsequently held that monetary compensation satisfied Section $5(2)(f)$ and that the statute did not require a "job freeze". ${ }^{11}$

Section $5(2)(f)$ expressly recognized that collective agreements might also protect the interests of employees. In the Nemitz case, the Supreme Court held that a collective agreement could not deprive an employees of any rights or level of protection contained in an earlier Commission order. ${ }^{12}$

Protection of employees against the impact of route or station abandonments took a different form than protection against mergers. The Interstate Commerce Act requires approval by the Commission of any abandonment. The statutory standard in the case of abandonments involves the "public convenience and necessity" in contrast to the more inclusive statutory stan-

5. See R. LIEB, LABOR IN THE TRANSPORTATION INDUSTRIES 44-45 (1974).

6. 49 U.S.C. $\$ 5(2)(b)$ (Supp. 1977).

7. St. Paul Bridge \& Terminal Ry. Control, 199 I.C.C. 588 (1934).

8. United States v. Lowden, 308 U.S. 225 (1939).

9. 49 U.S.C. $\S 5(2)(f)$ (Supp. 1977).

10. Railway Labor Executives Ass'n. v. United States, 339 U.S. 142 (1950), rev'g, New Orleans Union Passenger Terminal, 267 I.C.C. 763 (1948).

11. Brotherhood of Maintenance of Way Employees v. United States, 366 U.S. 169, 173-78 (1961).

12. Norfolk \& W.R.R. v. Nemitz, 404 U.S. 37 (1971); see Murray, note 1 supra. 
dard in the case of mergers of "consistent with the public interest". ${ }^{13}$ Relying on the difference in statutory language, the Commission originally refused to require any protection of employees as a condition to its approval of proposed abandonments. ${ }^{14}$ The Supreme Court overruled the Commission action and held that "public convenience and necessity" did require the Commission to consider the impact of abandonments on labor. ${ }^{15}$

After initially requiring proof of the adverse affects of abandonment on employment before approving relief for employees, the Commission eventually liberalized its policy and commencing with the Burlington case $^{16}$ has required severance pay in abandonment cases generally. The so-called Burlington formula (providing for $100 \%$, rather than $60 \%$, of compensation) for four years (or the employee's length of service, if less) has been uniformly applied in abandonment cases except in the case of a total abandonment by a carrier in extremis. ${ }^{17}$

The symbiotic relation between the statutory scheme and collective bargaining in the railroad industry was further strengthened when the Supreme Court in 1962 held that the Railway Labor Act required bargaining over a management decision to eliminate railroad stations (and station jobs). ${ }^{18}$

The Rail Passenger Service Act of 1970 (which established Amtrak) required "fair and equitable arrangements" to protect the interests of employees affected by discontinuance of intercity rail passenger service. ${ }^{19}$ The arrangements were to be approved by the Secretary of Labor. The protective provisions certified by the Secretary of Labor for displaced or dismissed employees were more liberal than the provisions of the Washington Job Protection Agreement in two fundamental respects. The dismissal allowance was increased to $100 \%$ of compensation from $60 \%$. Further, the period of compensation was extended from four to six years and commenced on the later date of actual displacement (rather than on the earlier date of the discontinuance). ${ }^{20}$

With continuing financial problems in the nation's rail system, the Congress passed the Regional Rail Reorganization Act of 1973 providing for the operation of the northeastern railroads. The 1973 Act contained employee protective provisions including severance pay modelled after the Washington Job Protection Agreement. In addition, the Congress appropriated $\$ 250,000,000$ to finance the implementation of the provisions. ${ }^{21}$ In the Rail Revitalization and Regulatory Reform Act of 1976, the foregoing provisions

13. Compare 49 U.S.C. $\S \S 1(18), 13 a(1)$ (1959) with 49 U.S.C. $\S 5(2)(b)$ (Supp. 1977).

14. E.g., Chicago, M., St.P. \& P.R.R. Trustees Abandonment, 240 I.C.C. 183 (1940); Chicago Great Western R.R. Trackage, 207 I.C.C. 315 (1935).

15. I.C.C. v. Railway Labor Executives Ass'n, 315 U.S. 373 (1942).

16. Chicago, B. \& Q. R.R. Abandonment, 257 I.C.C. 700 (1944).

17. See Brown, supra note 1 , at $452-53$

18. Order of Railroad Telegraphers v. Chicago \& N.W. Ry., 362 U.S. 330 (1962).

19. 45 U.S.C. $\$ \$ 541,565$ (1972).

20. P.L. 91-518, App. C-1, C-2, C-3, 83 Stat. 1327 (1970). See Congress of Railway Unions v. Hodgson, 326 F. Supp. 68, 76 (D.D.C. 1971).

21. 45 U.S.C. $\$ \$ 701,771-79$ (Supp. 1977). See Note, Railroad Reorganization under the Regional Rail Reorganization Act of 1973: An Overview, 40 AlBANy L. Rev. 812, 828, 862 (1976). 
were reaffirmed and expanded to cover railroads on a national, rather than regional, basis. ${ }^{22}$

In summary, since 1936, the railroad industry has been free to proceed with collective layoffs as a result of mergers and abandonments, but has been required to provide affected employees with significant compensation. This pattern has been adopted in the more recent statutes involving government reorganization of the industry. As has been recognized, one of the significant aspects of the development is that such employee protection has emerged as an incidental aspect of more important governmental concerns. ${ }^{23}$

\section{Motor Carriers, Water Carriers and Freight Forwarders}

Although $\S 5(2)(f)$ of the statute requiring "a fair and equitable arrangement" is restricted to railroad employees, $\S 5(2)(c)$ of the Act requires the Commission to give weight to the interest of employees of motor, as well as rail, carriers in passing on certificates and permit transfers. Despite the omission in $\S 5(2)(f)$, the statute has been construed to give the Commission power to include employee protective provisions in motor carrier cases. ${ }^{24}$ Unlike the railroads, motor carriers represent an expanding industry with greater job opportunities for displaced employees. ${ }^{25}$ Accordingly, motor carrier employees have received less protection than rail employees.

The Commission is also authorized to provide employee protection in the case of the merger or consolidation of water carriers and the transfer of freight forwarding permits. ${ }^{26}$

\section{Air Lines}

In administering the Federal Aviation Act providing for regulation of commercial air carriers, the Civil Aeronautics Board ("the Board"). has followed the pattern established over the railroads by the Interstate Commerce Commission.

Although the Federal Aviation Act contains no provisions for the protection of employees, Section 1378 (b) provides that approval by the Board is required for all airline mergers, purchases, leases, control acquisitions and route changes and requires a finding that the transaction is "consistent with the public interest."27 Although the Act is silent with respect to the transfer

22. 45 U.S.C. $\$ 8801,836$ (Supp. 1977).

23. See P. Selznick, LAw, Society, AND Industrial Justice 221-22 (1969).

24. American Bus Lines, Inc. v. U.S.A., 253 F. Supp. 481,483 (D.D.C. 1966), aff'd sub. nom. Amalgamated Transit Union v. U.S.A., 385 U.S. 38 (1966); see Amalgamated Ass'n. of Street, Electric Ry. \& Motor Coach Employees v. U.S.A., 221 F. Supp. 958, 959-60 (D.D.C. 1963); Brotherhood of R.R. Trainmen v. U.S.A., 272 F. Supp. 304, 306 (E.D. Pa. 1967); Meck \& Bogue, Federal Regulation of Motor Carrier Unification, 50 YALE L.J. 1376, 1408-09 (1941).

25. See Lieb. supra note 5, at 6 (total employment of Class I Motor Carriers increased from approximately 375,000 in 1960 to approximately 500,000 in 1970).

26. In considering water carrier mergers or consolidations, the Commission must find that the transaction is "consistent with the public interest", 49 U.S.C. $\$ 912$ (1963). Under the Lowden case, supra, it has the discretion to impose employee protective conditions in its order of approval. The Commission is under a duty to provide a "fair and equitable arrangement to protect the interests of the employees affected" by a transfer of freight forwarding permits. 49 U.S.C. $\$ 1010(\mathrm{~g})(1963)$.

27. 49 U.S.C. $\S \S 1301,1378$ (b) (1970). 
of certificates of public convenience and necessity, it expressly provides that in the case of the related acquisition of physical assets, the Board may grant approval "upon such terms and conditions as it [the Board] shall find to be just and reasonable." ${ }^{28}$ Utilizing these provisions in the same manner as the Interstate Commerce Commission action upheld in the Lowden case, the Board in 1947 in the United Western case first required the protection of employees as a condition for approval of mergers and route changes. ${ }^{29}$ This became the accepted policy of the Board in numerous cases. ${ }^{30}$ Finally in the United-Capitol Merger Case in 1961, the Board enunciated a fully developed program of employee protection embracing thirteen conditions, including severance pay ( $60 \%$ for a period of five years depending on length of service), displacement allowances, and the integration of seniority lists for the protection of employees. ${ }^{31}$ This became the standard for subsequent cases.

In essence, the Washington Job Protection Agreement was largely borrowed from the railroad experience to provide the guiding policy for the Board. In so doing, the Board has been criticized for "blindly" following the Interstate Commerce Commission ${ }^{32}$ despite the contrast between the vigorously expanding airline industry and the declining railroads. Thus, scheduled airline carriers increased employment from 166,235 in 1960 to 292,185 in 1971, while empioyment on railroads was declining from 626,100 in 1960 to 566,300 in 1970.33

Encouraged by the Secretary of Labor's liberalization of protective provisions in his 1970 Amtrak decision, the air labor unions pressed for an increase in dismissal payments from $60 \%$ (as in the Washington Job Protection Agreement) to $100 \%$ (as in the Amtrak decision) and for other improvements in employee protective provisions.

These proposals were resisted by the air carriers and rejected by the Board which stated that its standard provisions adopted in the UnitedCapitol Merger Case were successful and that no change was desirable. ${ }^{34}$

\section{Other Regulated Utilities}

The Communications Act of 1943 provides protection for employees of telegraph (but not of telephone) companies in the event of layoff or displacement as a result of merger. In the event of discharge as a consequence of a merger within four years of the date of merger approval, employees became entitled to severance pay equal to four weeks pay per year of prior service. Discharged employees were also granted preferential hiring status for new positions for which they were qualified. The Act further provided for moving expenses for relocated personnel. ${ }^{35}$

28. 48 U.S.C. $\S 1378(b)(1970)$.

29. United-Western Acquisition of Air Carrier Property, 8 C.A.B. 298 (1947), 11 C.A.B. 701 (1950); see Brown, supra note 1 , at 456-59.

30. See cases collected in Rosenfield, supra note 1 , at 435 n. 30.

31. United-Capital Merger Case, 33 C.A.B. 307, 323-31, 342 (1961).

32. See Rosenfield, supra note 1 , at 450-51,459.

33. See Lieb, supra note 5 , at $2,8,21$.

34. Northwest-Northeast Merger Case, No. 21819, Order Nos. 70-12-162, 70-12-163, at 22; (C.A.B. Dec. 31, 1970). Allegheny-Mohawk Merger Case, No. 23371, Order Nos. 72-4-31, 72-4-32 (C.A.B. March 28, 1972) cited by Rosenfield, supra note 1, at $445 \mathrm{n} .87$ and $446 \mathrm{n} .89$. 35. 45 U.S.C. \& $222(f)(1962)$. 


\section{Urban Mass Transportation}

The Urban Mass Transportation Act of 1964 is the cornerstone of the federal transit program. Along with provisions for aid to urban transit systems and the planning and establishment of mass transportation programs, the Act provides that "fair and equitable arrangements" shall be made to protect the interests of employees affected by the programs financed under the Act. The Act also provides for training and retraining programs and priority for reemployment of affected employees. ${ }^{36}$

The Act contains no provision for severance pay, although severance pay would be available if provided in applicable collective bargaining agreements, or under Section 5(2)(f) of the Interstate Commerce Act where railroad transit employees are involved.

\section{Pollution Control Acts}

The Water Pollution Control $\mathrm{Act}^{37}$ and the Solid Waste Disposal Act ${ }^{38}$ require the Administrator, upon request of any affected employee, to hold a public hearing and to report any discharge, layoff, plant closing, or reduction in employment as a result of any limitation, implementation, or administrative order under the statutes.

Although the Acts contain no provision for compensation or assistance to affected employees, the existence of the procedure wiil likely act as a pressure on the administrative agencies to take employee interests into account in the consideration and formulation of limitations and orders under the Acts.

\section{Proposed Federal Legislation}

There appears to be some increasing interest in governmental action to deal with contemplated plant closings and relocations.

A bill to enact the proposed National Employment Priorities Act to deal with this problem among others was introduced in the Congress by Senator (now Vice President) Mondale in 1973 and has been reintroduced in the subsequent Congresses. The 1977 Bill contains a declaration by the Congress of its concern with "arbitrary and unnecessary closings and transfers" of business and agricultural establishments and of its view that concerns "wishing to close" or to "transfer . . . operations" "should take into account the social and community needs of employees." 39

The bill would require concerns with 50 employees or more intending to close or transfer all or part of the operations of a business establishment which would result in unemployment in the affected establishment to provide the Secretary of Labor with two years prior notice of the closing or transfer.

The Secretary of Labor would be authorized to investigate, hold hearings, and report on the matter and would be required to do so at the request of labor. In appropriate cases, the Secretary of Labor would be authorized:

36. 49 U.S.C. $\S 1601,1609$ (c) (1970).

37. 33 U.S.C. $\$ 1267$ (e) (1977 Supp).

38. 42 U.S.C. \& 6971 (e) (1977 Supp.).

39. H.R. 76, 95th Cong., 1st Sess. (1977). 
1. to provide assistance to affected employees, including payments for income maintenance, maintenance of health and pension benefits, relocation allowances, and retraining assistance.

2. to provide assistance to affected communities, including grants to offset the loss of tax revenues and loan guarantees to communities or to private enterprises for the purpose of expanding job opportunities.

3. to provide technical or financial assistance, including loans and loan guarantees to concerns planning to close or transfer to prevent or alleviate potential employment loss.

The bill would further authorize the Secretary of Labor to withdraw important tax benefits in the event he found that the closing or transfer was not justified or could have been avoided if the concern had accepted assistance available under the law. The tax benefits, that would be lost for a period of 8 years, would include the investment tax credit, the accelerated depreciation deduction, the foreign tax credit, the provision for deferral of income earned outside the United States, and the deduction of expenses related to the transfer. Similarly, favorable tax treatment for industrial development bonds issued in connection with the financing of the new location would be unavailable.

The bill is a reflection of the significant increase in national concern over the impact of plant closings and relocations on affected employees and communities. If the National Employment Priorities Act is enacted in the form proposed, the United States would become firmly commited to the principle of governmental intervention in the case of collective layoffs. At the time of writing this review hearings had not been held on the bill and its chances of passage were not regarded as promising.

\section{Conclusion}

In summary, a comprehensive system of governmental regulation in the transportation industry has included as an incident far-reaching protective provisions for employees adversely affected by mergers, route changes and abandonments in the form of severance pay in the event of dismissal, displacement allowances for poorer jobs, moving and retraining allowances, and protection of seniority. These have become an accepted aspect of American economic life in these industries resting in part on statute, in part on administrative regulation, and in part on collective bargaining agreements.

Concern with employee protection is receiving recognition in statutory enactments in other areas, such as environmental control, but is still in its early stages. These statutory provisions are restricted to information gathering and publicity, but may be regarded as a forerunner to consideration of the more extensive protective provisions applicable to railroads and airlines.

In other industrial areas not generally subject to governmental regulation or control, there is no statutory or administrative intervention whatsoever, and employees must look to private law making through collective bargaining as their sole protection with respect to layoffs and displacement as a result of mergers, relocations, and plant closings. 


\section{Private Law Making: Collective Bargaining}

As has been observed, in the United States protection of employee rights and employee participation in corporate decision-making-where they exist at all-are usually found in collective bargaining agreements rather than in statute or administrative regulation. ${ }^{40}$ This general observation applies to labor participation in decisions on plant relocations, plant closings and work transfers as well. As we have seen, federal statutory or administrative controls over such matters are largely restricted to the transportation industry. In the industrial world as a whole, collective bargaining agreements tend to be the only source of protection of employee rights.

The National Labor Relations Act ("the Labor Act") ${ }^{41}$ imposes a statutory obligation on the employer to bargain and creates an elaborate administrative machinery for the implementation of the bargaining process and for the enforcement of collective agreements. The substantive protection of employees, however, is the product of private lawmaking embodied in the collective agreement.

\section{Collective Bargaining for Job Security}

Job security provisions, and particularly employer obligations to consult with, or obtain union approval of, plant closings, plant relocations, or work transfers are features of only a minority of collective agreements. Thus, a 1969 survey disclosed that $21.5 \%$ of the agreements included in the survey, covering nearly $3,000,000$ workers, contained restrictions of some nature of management's right to close or relocate a plant. ${ }^{42}$ An earlier survey of agreements covering 7,500,000 workers found that about one fourth of the agreements contained some form of limitation on the subcontracting of work. ${ }^{43}$ In contrast, under most agreements, American employers have been able to include a management control clause preserving exclusive management decision over such matters as mergers, plant relocations, and shutdowns. ${ }^{44}$

The existence or nonexistence of such provisions in collective agreements, of course, reflects the relative economic strength of employers and unions in the bargaining process and their respective priorities.

Even where collective agreements do not deal directly with such matters, the arbitration process may result in limitations on managerial discretion.

40. See Bok, Reflections on the Distinctive Character of American Labor Laws, 84 HaRv. L. Rev. 1394 (1971), D. BOK \& J. Dunlop, LABOR AND THE AMERICAN CoMmunity 20814 (1970).

This discussion draws upon the author's contribution on the topic at IX Congress of Comparative Law, Teheran, Iran, 1974. See Blumberg, Employee Participation in Corporate Decision Making in the United States: A Summary Review in HAZARD AND Wagner eds., Law in the United States of America in Social and Technological REVOLUTION 327, 336-340 (1974).

41. 29 U.S.C. \& 151 (1970).

42. See Rabin, Fibreboard and the Termination of Bargaining Unit Work. The Search for Standards in Defining the Scope of the Duty to Bargain, 71 Colum. L. REv. 803, 821-22 (1971).

43. See Fibreboard Paper Products Corp. v. NLRB, 379 U.S. 203, 212 n. 7 (1964).

44. See F. Baerwald, Economic Progress and Problems of LABor 359-60 (2d ed. 1970) (quoting 1966 U.S. Dept. of Labor survey showing that 860 of 1773 collective agreements surveyed contained management control reservations.). 
Arbitrators may find implied obligations regulating managerial discretion in these areas and require a demonstration of "good faith" or "fair dealing", evidenced by a rational basis for the management decision relating to efficient operations and reflecting concern for employee interests and expectations. ${ }^{45}$

Thus, it appears that even where a union agreement exists, American management is free as a matter of contract law in most cases to make such fundamental business decisions without labor consultation or approval. The Labor Act, however, as we will see, may require the employer to bargain nevertheless. It hardly needs to be noted that except for the few regulated industries in which statutory or administrative control has been asserted, employers, not subject to union agreements and whose employees are not represented by a union, have an entirely free hand. Since only about 20 million, ${ }^{46}$ or one fourth, of $86,000,000$ American workers are unionized, the overwhelming bulk of American labor is without job protection. The point, however, should not be over-stated. American unionization is concentrated in the industrial or manufacturing sector, which is the area of greatest concern with respect to plant closings and relocations. Union influence as a practical matter is therefore more important than would appear from the bare statistics. Further, service and non-profit industries and government employment which represent the areas of greatest recent growth in total employment rarely involve the problems of plant closings and relocations with which this survey is concerned.

\section{The Employer's Duty to Bargain on Job Security}

The Labor Act requires an employer to bargain over "terms and conditions of employment" with a union representing a majority of employees in a bargaining unit. ${ }^{47}$ In their effort to limit managerial power over decisions affecting job security, American unions have exerted substantial pressure on the National Labor Relations Board ("the Labor Board") to hold that management's duty to bargain over "terms and condition of employment" includes a duty to bargain on such decisions as the sale or relocation of a plant or the subcontracting of work. ${ }^{48}$

Prior to 1962, the Labor Board refused to impose a duty upon employers to bargain over a decision to sell or relocate or close a plant or to subcontract

45. E.g., see Allis-Chalmers Manufacturing Co., 39 Lab. Arb. 1213 (1962) (Smith, Arbitrator).

46. 1975 Statistical Abstract United States Table No. 604, at 375.

47. 29 U.S.C. $\S 158(a)(1),(5)(1970)$.

48. See R. Gorman, Basic Text on Labor Law, Unionization and Collective BarGAINING 509-23 (1976); Swift, Plant Location: Catching up with the Runaway Shop, 14 B.C. IND. \& CoM. L. REv. 1135 (1973); Rabin, The Decline and Fall of Fibreboard, 24TH ANN. CONF. ON LABOR 237-266; Rabin, supra note 42, at 822; Schwartz, Plant Relocation or Partial Termination-The Duty to Decision-Bargain, 39 FORD. L. REv. 81 (1970); Comment, The National Labor Relations Board's Pursuit of the Runaway Shop, 7 VILL. L. REV. 450 (1972).

A related area not within the scope of this review concerns the duty of a purchaser of an established business to bargain with the union representing the seller's employees or to be bound by the seller's collective agreement. $C f$. John Wiley \& Sons v. Livingston, 376 U.S. 543 (1964); N.L.R.B. v. Burns Int'l Security Services, 406 U.S. 272 (1972); Howard Johnson Co. v. Detroit Local Joint Executive Board; 417 U.S. 249 (1974). 
work. Employers were held under a duty to bargain only over the impact upon the employees adversely affected by such decisions. ${ }^{49}$

In 1962, the Labor Board changed its policy and held in Fibreboard Paper Products ${ }^{50}$ that an employer was required under the Labor Act to bargain over a decision to subcontract the maintenance work at its plant previously performed by its own employees. The Supreme Court affirmed. ${ }^{51}$ The Supreme Court noted that subcontracting generally had widely been the subject of collective bargaining, that the instant decision to subcontract did not alter the employer's basic operation, contemplated no capital investment, and involved only the substitution of the contractors' employees for existing employees to do the same work. It concluded that: "to require the employer to bargain about the matter would not significantly abridge his freedom to manage the business" ${ }^{52} \mathrm{Mr}$. Justice Stewart, concurring, emphasized that "managerial decisions, which lie at the core of entrepreneurial control" were not subject to any duty to bargain..$^{53}$

After Fibreboard, the Labor Board read the employer's duty to bargain under the Act very widely and required employers to bargain over a wide spectrum of decisions affecting job security, including decisions to close or relocate plants, to sell part of the business, to automate, to reorganize, or to transfer work between plants although valid business reasons supported the decision and no anti-union objective could be shown. ${ }^{54}$

The expanded construction of the Labor Act by the Labor Board was not upheld by the Courts. The Courts of Appeal refused to enforce the Board's orders to bargain over decisions in numerous cases. ${ }^{55}$ At the same time, the duty to bargain over the impact of the decisions was uniformly upheld. ${ }^{56}$

49. Brown-Dunkin Co., 125 N.L.R.B. 1379 (1959), enforced, 287 F. 2 d 17 (10th Cir. 1961); see cases collected in Note, Employer's Duty to Bargain about Subcontracting and Other "Management Decisions", 64 CoLUM. L. REv. 294, 301 (1964).

50. 138 N.L.R.B. 550 (1962). Accord: Town \& Country Mfg. Co. 136 N.L.R.B. 1022, 1027, enforced, 316 F. 2d 846 (5th Cir. 1963).

51. Fibreboard Paper Products Corp. v. N.L.R.B., 379 U.S. 203 (1964).

52. Id. at 213.

53. Id. at 223.

54. E.g. Ozark Trailers, Inc., 161 N.L.R.B. 561 (1966); Royal Plating \& Polishing Co., Inc. 160 N.L.R.B. 990 (1966), enforcement denied sub nom. N.L.R.B. v. Royal Plating \& Polishing Co., Inc., 350 F. 2d 191 (3d Cir. 1965); Weltronic Co., 173 N.L.R.B. 235, enforced sub nom. N.L.R.B. v. Weltronic Co. 419 F. 2d 1120 (6th Cir. 1969); Drapery Mfg. Co., 170 N.L.R.B. No. 199 (1969), enforcement denied sub nom. N.L.R.B. v. Drapery Mfg. Co., 425 F. 2d 1026 (8th Cir. 1970); Thompson Transp. Co., 165 N.L.R.B. 746 (1967), enforcement denied sub nom. N.L.R.B. v. Thompson Transp. Co., 406 F. 2d 698 (10th Cir. 1968); Transmarine Navigation Corp. 152 N.L.R.B. 998 (1965), enforcement denied sub nom. N.L.R.B. v. Transmarine Navigation Corp., 380 F. 2d 933 (9th Cir. 1967); Adams Dairy Co. 137 N.L.R.B. 815 (1962), enforcement denied sub nom. N.L.R.B. v. Adams Dairy, Inc., 350 F. 2d 108 (8th Cir. 1965), cert. denied, 382 U.S. 1011 (1966); see Rabin, note 48 supra, at 24445.

55. N.L.R.B. v. Royal Plating \& Polishing Co., Inc., 350 F. 2d 191 (3d Cir. 1965); N.L.R.B. v. Acme Industrial Products 416 F. 2 d 40 (6th Cir. 1971); N.L.R.B. v. Drapery Mfg. Co., 425 F. 2d 1026 (8th Cir. 1970); N.L.R.B. v. Transmarine Navigation Corp., 380 F. 2d 933 (9th Cir. 1967); N.L.R.B. v. Thompson Transp. Co., 406 F. 2d 698 (10th Cir. 1968) Contra: N.L.R.B. v. Winn-Dixie Stores, Inc. 361 F. 2d 512 (5th Cir. 1966). See Swift, supra note 48 , at 1151 n. 96 (1973).

56. E.g., N.L.R.B. v. Royal Plating \& Polishing Co., Inc., 350 F. 2d. 191, 196 (3d Cir. 1965); N.L.R.B. v. Drapery Mfg. Co., Inc., 425 F. 2d. 1026 (8th Cir. 1970). 
In 1971, the Board retreated and abandoned its previous expanded construction. In the General Motors case, the Board held that the Labor Act did not require bargaining over an employer's decision to close or sell part of its business; this involved the disposition by General Motors of its truck sales and service center in Houston in which the purchaser of the trucks and equipment leased the premises from General Motors and received a truck dealership franchise. The Board followed the rationale of the courts and said that there was no duty to bargain over decisions involving "a significant investment or withdrawal of capital" or "matters essentially financial and managerial in nature". ${ }^{77}$

At about the same timè, in Summit Tooling, the Board held that a parent company was under no duty to bargain over a decision to shut down its wholly owned subsidiary and terminate the subsidiary's manufacture of tools and tooling products. ${ }^{58}$

The Board's retreat was no doubt influenced not only by the hostile reception that its more expansive construction had received in the Courts of Appeal but also by the Supreme Court decision in the Darlington case in which the Court held that an employer had no duty to bargain over a decision to shut down its entire business. ${ }^{59}$

In International Union, UAW $v$. NLRB, enforcing General Motors, the Court of Appeals for the District of Columbia Circuit borrowed Mr. Justice Stewart's words in his concurrence in Fibreboard and held that the employer decision there involved was "at the core of entrepreneurial control" and therefore outside the duty to bargain. The Court said that bargaining was not required in cases which involved "the termination of a substantial portion or a distinct line of the employer's business or involved a major change in the nature of its operations" unless it was "primarily designed to avoid the bargaining agreement."

The Board has not entirely abandoned its earlier view as illustrated by a number of decisions after General Motors. In Royal Typewriter, the Board held that a large conglomerate employer was under a duty to bargain over a decision with respect to the closing of one of a number of plants. The Board distinguished General Motors as a decision to sell a dealership and Summit Tooling as a decision to go out of a particular line of business. ${ }^{61}$ Similarly, the Board continues to impose a duty to bargain over a decision to transfer work from one plant to another where relocation does not substantially alter the conduct of the business or its operations or where no significant investment or withdrawal of capital is involved. ${ }^{62}$ Finally, bargaining over subcon-

57. General Motors Corp., 191 N.L.R.B. 951 (1971) enforced sub nom. International Union, UAW v. N.L.R.B., 470 F. 2d 422 (D.C. Cir. 1972). See 1971-1972 Annual Survey of Labor Relations Law, 13 B.C. IND. \& CoM. L. REv. 1347, 1408-13 (1972); 1972-1973 Annual Survey of Labor Relations Law, 14 B.C. IND. \& COM. L. REV. 1173, 1207-09 (1973).

58. Summit Tooling Co., 195 N.L.R.B. 479 (1972).

59. Textile Workers v. Darlington Mfg. Co., 380 U.S. 263 (1965).

60. 470 F. $2 d$ at 424 .

61. Royal Typewriter Co., 209 N.L.R.B. 1006 (1974), enforced 333 F. 2d 1030 (8th Cir. 1976) (court did not pass on this issue since no remedial relief ordered but indicated its disapproval).

62. Kronenberger d/b/a/ American Needle \& Novelty Co., 206 N.L.R.B. 534 (1973). 
tracting of work continues to be required where not accompanied by a withdrawal of capital. ${ }^{63}$

It should be noted, however, that even in the cases where the Labor Board has held that an employer was under a statutory duty to bargain, there is no obligation on the employer to reach an agreement. An impasse in the negotiations may develop without any violation of the Act. ${ }^{64}$

Thus, the Labor Act no longer provides a broad statutory base for unions to utilize the bargaining process to play a participative role in fundamental management decisions affecting job security. Nevertheless, even in the absence of a statutory duty to bargain, the economic power of unions will in some cases be sufficient to cause job security protection to be inserted in the ultimate agreement. Since there is no statutory duty to bargain over such matters, it is an unfair labor practice for a union to strike to compel an employer to bargain over such a provision. ${ }^{65}$

\section{Current Pressures for Lifetime Job Security}

In the 1977 collective bargaining negotiations between the United Steel Workers of America and the steel industry, a major American union for the first time demanded lifetime job security for employees. This has been described as a development that could "revolutionize" labor relations in the United States. ${ }^{66}$

The union demand included a guaranteed minimum amount of work per year, restrictions on the use of outside contractors, and the availability of early retirement with full benefits for employees displaced by plant closings or technological developments. ${ }^{67}$.

The final agreement took only limited steps in the direction of strengthened job security. In what President McBride of the Steel Workers described as a start on the union's goal of lifetime job security, the agreement provided increased job protection for senior employees. Laid off workers with 20 years or more of service are to be provided with "appropriate work" at their previous plant or "suitable long-term employment" at other locations; provision is also made for early retirement. ${ }^{68}$

Although the Steelworkers' demand for lifetime job security was not recognized in the final agreement, it reflected the growing concern over longterm job security on the part of strongly entrenched unions which have already achieved high wages, pension and health benefits, and satisfactory working conditions for their members. It is believed that such demands will be more common in the future. Further developments are already anticipated in the aluminum, copper and canning industries.

Many American union contracts have provided limited job security and income maintenance during periods of layoff. In the automobile and steel

63. Florida-Texas Freight, Inc., 203 N.L.R.B. 509 (1973).

64. See Morris, The Developing Labor Law 330-32 (1971); H. Wellington, Labor AND the Legal Process 73-74 (1968).

65. N.L.R.B. v. Borg-Warner Corp., 356 U.S. 342 (1958).

66. Business WEEK, Feb. 28, 1977, at 28.

67. Wall St. J., Feb. 15, 1977, at 2.

68. N.Y. Times, June 5, 1977, § 3, at 5: The Economist, Apr. 16, 1977, at 47. 
industries, for example, supplemental unemployment benefit programs provide substantial income for an extended period; in automobiles, $95 \%$ of wages for a twelve-month period, and in steel for twenty-four months. ${ }^{69} \mathrm{~A}$ study by the Bureau of Labor Statistics as of July 1, 1973 disclosed that out of 1339 agreements in the survey (exceeding airlines and railroads), 169 covering 975,900 workers, primarily in nonmanufacturing industries, provided for wage employment guarantees; 441 covering 3,078,300 workers, mostly in transportation equipment, communications, and primary metals, provided for severance pay; and 218 covering 1,939,350 workers, primarily in manufacturing, provided for supplemental unemployment benefits. ${ }^{70}$ Lifetime job security goes far beyond such proposals and presents serious economic questions for employers in view of the possibility, if not probability, of changing market conditions and technological developments over the long-term.

\section{Conclusion}

In summary, notwithstanding the ultimate position of the Labor Board restricting the extent of the employer's duty to bargain under the Labor Act, the collective bargaining process, its day-to-day administration, and its arbitration machinery have provided American labor with some limited influence over managerial decisions with respect to collective layoffs and with significantly greater participation with respect to the provision to be made for employees adversely affected by such layoffs.

\section{Common-Law or Constitutional Protection Against layoffs}

Although there has been some intellectual discussion in the United States with respect to a worker's property interest in his or her job based on the common-law or under the Federal Constitution, ${ }^{71}$ there is no judicial authority providing direct support for this advanced view.

In the United States, the employment relation is at will, except to the extent protected by statute or contract. At common law, the employer's freedom to discharge was absolute. Over the years, this right of discharge has been increasingly restricted by statute and collective agreements but the basic principle of the employer's legal right to discharge, despite the theoretical challenges, is still unimpaired. ${ }^{72}$

Statutes prohibit employment discrimination by reason of age, ${ }^{73}$ race, color, religion, sex, national origin, ${ }^{74}$ union activity ${ }^{75}$ or physical handicap. ${ }^{76}$

69. N.Y. Times, Feb. 17, 1977, at 29.

70. BNA, 1 Collective Bargaining, Negotiations \& Contracts, 16:8:21.

71. See F. Meyers, OWnership of Jobs: A Comparative Study (1964); Selznick, supra note 23: McClintock, Enterprise Labor and the Developing Law of Rights, 8 Gonz. 40, 217 (1972-73)

72. See Blades, Employment at Will $v$. Individual Freedom on Limiting the Abusive Exercise of Employer Power, 67 CoLUM. L. REV. 1404 (1967); Blumrosin, Employer Discipline: United States Report, 18 RuTG. L. REv. 428 (1964).

73. Age Discrimination in Employment Act, 29 U.S.C. $\$ 623$ (Supp. 197.3).

74. Civil Rights Act of 1964,42 U.S.C. $\$ 2000 \mathrm{e}-2$ (1970).

75. National Labor Relations Act, 29 U.S.C. § 158(a) (1973).

76. Rehabilitation Act of 1973, 29 U.S.C. $\$ 794$ (1975) (programs rece!ving Federal financial assistance only). 
Collective agreements almost invariably require "just cause" for discharge, ${ }^{77}$ and as we have seen in some cases may even provide some protection against collective layoffs. Yet, except for such restrictions, the American employer is free to discharge its work force as a group or individually without notice or severance pay for any reason, or for no reason at all provided that the discharge is not motivated by malice. ${ }^{78}$

In a number of recent cases, this established state of the law has been directly challenged but entirely without success.

In Charland $v$. Norge Division, Borg-Warner Corp. ${ }^{79}$ an employee with 30 years of service was discharged as a result of his employer's decision to relocate the plant. Under the settlement agreement between the employer and the employee's union, the employer offered the employee either a lump sum of $\$ 1500$ or an opportunity along with the residents of the new location to compete for a job at the new plant with complete loss of his seniority.

The employee brought suit alleging that he had a vested property right in his job and seniority which could not be taken away under the Fifth and Fourteenth Amendments prohibiting deprivation of property without due process of law.

The Court of Appeals for the Sixth Circuit dismissed the claim, stating:

Thus appellant's assumption submits the fundamental question of whether or not there is a legally recognizable property right in a job which has been held for something approaching a lifetime.

The claim presented by this appellant brings sharply into focus such problems as unemployment crises, the mobility of capital, technological change and the right of an industrial owner to go out of business . . . . Thus far federal law has sought to protect the human values to which appellant calls our attention by means of such legislation as unemployment compensation, . . . and social security laws . . . . These statutes afford limited financial protection to the individual worker but they assume his loss of employment.

Whatever the future may bring, neither by statute nor by court decision has appellant's claimed property right been recognized to date in this country. ${ }^{80}$

At least four other courts have reached the same conclusion. ${ }^{81}$

77. See Comment, Industrial Due Process and Just Cause for Discipline: A Comparative Analysis of the Arbitral and Judicial Decisional Process, 6 U.C.L.A. L. REv. 603 (1959); SELzNICK, supra note 23, at 154-78, 229-30.

78. Monge v. Beebe Rubber Co., 114 N.H. 130, 316 A. 2 d 549 (1974), 7 ConN. L. REv. 758 (1975) (discharge unlawful when maliciously motivated by reason of female employee's rebuff of manager's advances). Judicial concern with protection of the judicial system or frustration of statutory policy may make a discharge actionable. Nees v. Hocks, 536 P.2d 512 (Ore. 1975) (dismissal because of absence on jury duty held wrongful); Petermann v. Teamsters Union, 174 Cal. App. 2d 184, 344 P.2d 25 (1959) (dismissal for refusal to commit perjury held wrongful); Frampton v. Central Indiana Gas Co., 297 N.E.2d 425 (Ind. 1973) (dismissal for filing workmen's compensation claim held wrongful).

79. 407 F.2d 1062 (6th Cir. 1969), cert. denied, 395 U.S. 927 (1969).

80. 407 F. 2d at 1064 .

81. Vaughn v. Chrysler Corp., 382 F. Supp. 143, 144 (E.D. Mich. 1974) ("Plaintiffs have not set forth any contract of employment or labor management agreement. Absent such contracts or agreements, there exists no independent and legally cognizable property 
Protection of employees against layoff through the recognition of a legal property interest in their jobs does not appear a likely development in the forseeable future.

\section{Reflections on the AMERICAN EXPERIENCE}

In summary, it appears that in the United States, protection of employees against collective layoffs is spotty and limited.

An exception is the transportation area where it has been an established feature for decades. Federal regulatory control over transportation provides protection for employees adversely affected by mergers and abandonments as an essential element of the federal administrative agency's decision with respect to the proposed transaction. Moreover, in the railroad industry, collective agreements have significantly strengthened the statutory and administrative protection for employees. Only a small minority of American workers, however, are employed in industries covered by federal regulatory control and the provisions for their protection are hardly typical.

Outside of transportation, collective bargaining agreements cover only a small minority of all American workers, although they do include most American workers engaged in manufacturing. Only about a fifth to a quarter of the collective agreements, however, provide a contractual basis for the unions to participate in decision-making with respect to plant closings, relocations, work transfers and other causes of collective layoffs. Further even in these cases, the protection provided employees tends to be restricted. The steel workers union has begun to press for so-called lifetime job security, but it is still much too early to tell how serious an objective this is or how successful it will ultimately be.

The Labor Act provides another source for union participation in cases where it represents a majority of employees in the bargaining unit. As we have seen, however, after a liberal expansion from 1962 to 1971 , the Labor Board finally construed the employer's duty to bargain over decisions of this nature in restrictive terms and little remains. On the other hand, the duty to bargain over the impact of such decisions continues unimpaired. In such cases, labor may not be able to prevent the collective layoff, but it may gain financial relief for, or protect the seniority of, employees adversely affected.

Thus, in the aggregate, American labor is more significantly protected against some of the impact of collective layoffs than is generally recognized, but the extent of such protection, with exceptions, is limited and embraces a small minority of the total work force.

right to a job which one has held for a number of years"); Percival v. General Motors Corp., 539 F.2d 1126 (8th Cir. 1976) (discharge for allegedly refusing to give false information to the government not actionable; Geary v. U.S. Steel Corp., 456 Pa. 171, 319 A.2d 174 (1974) (discharge for allegedly giving warning of a dangerous product not actionable. See Burke v. Mathiasen's Tanker Industries, Inc., 393 F. Supp. 790, 792 (E.D. Pa. 1975) ("An employee does not have a property right in his employment. . ."). 